\title{
THE IMAGE OF
}

\section{A WOMAN IN}

\section{THE TRADITIONAL}

KAZAKH

МРНТИ 02.91.91

УДК 1(091)(4/9)

DOI 10.47940/cajas.v5i4.290

\section{GULZHIKHAN NURYSHEVA, BANU KALDAYEVA}

${ }^{1}$ Al-Farabi Kazakh National University (Almaty, Kazakhstan)

WORLDVIEW

\section{THE IMAGE OF A WOMAN IN THE TRADITIONAL KAZAKH WORLDVIEW}

\section{Abstract}

The article is devoted to the image of a woman in the traditional worldview of the Kazakh people.

Traditional worldviews that are divided into historical types and the evolution of ideas and trends associated with the problem of women which took place at these stages are being studied. It is important to consider the problem of women in the context of the traditional worldview. This is due to the fact that trends and stereotypes about the social role of gender are formed on the basis of deeply rooted ideas that are traditionally passed down from generation to generation. These concepts have evolved over a long history of society and have different aspects: historical, social, economic, political, cultural, religious. Since the central core of all this is the worldview of people, it is important to analyze the image of a woman in the traditional worldview. This allows us to understand the evolutionary path of society's understanding of women's problems and its foundations. To preserve one's identity in the context of today's globalization, it is necessary to study the traditional system of values of the Kazakh people, the evolution of the system of ideas about the place and role of men and women in society, the historical experience of the people in relation to gender relations.

In today's world, the globalization of culture and the national renaissance go hand in hand. In the culture of the 21st century, on the one hand, a common world culture of the whole planet is being formed, on the other hand, there is a growing interest in the cultural diversity of each nation and its development. The relationship between cultural heritage and modern culture is clearly reflected in the relationship between tradition and modernity in the image of today's Kazakh woman. Any culture is not established by force in a short time, the factors that regulate the culture of the people are formed over the centuries. Therefore, it is important to systematize the image of the Kazakh woman in modern culture, starting from the analysis of the image of mother in Kazakh mythology, motherhood in the Kazakh genealogy, the image of women in the heroic songs, as well as the image of women in the works of poets.

Key words: image of a woman, traditional Kazakh worldview, essence of a woman, "the concept of a Kazakh woman", folklore. 


\section{Introduction}

The issue of studying the image of women has never been neglected. For centuries, the soul, the mysterious world, the tenderness, the beauty, the wisdom, the courage, the moral qualities of a woman have been a special theme. With its mysterious nature and beauty, the innermost secrets, feelings, thoughts and emotions of a woman, who have always been the basis of poetry and work, have been deeply rooted for centuries as a unique issue.

In the history of the Steppe, there were many outstanding women who became the greatest pride of the nation. In the pleiad of prominent women of the world the great queen of the Massagetae Saka Tomyris, who overthrew the king Cyrus the Great, the founder of the great Persian Empire. It is worth noting the daughter of the Saka king, the wife of the commander Mermer, the ruler of the whole city Roxonaki, about whom there is a beautiful legend that made her a symbol of justice and patriotism. We must remember the powerful and warlike Boarix, the queen of the HunnoSavirian Union, who owns the historical merit of concluding a peace treaty with the Byzantine Empire. We all know and are proud of our heroines - Aliya Moldagulova, Manshuk Mametova, Hiuaz Dospanova. Kazakh poet, composer and philosopher Abai Qunanbaiuly became a great son of the Kazakh Steppe thanks to his mother Ulzhan and grandmother Zere. We are also proud of the famous composer-kuishi (dombyra player) Dina Nurpeisova, who was recognized as the National Artist of Kazakhstan for her musical accomplishments.

In traditional Kazakh history there were known numerous women who ruled people, mothers who ruled whole tribe, heroines who were known for their braveness, and women who were worshipped because of their sacred qualities, famous orators and very well- known musicians. Some of them were forgotten in the pace of history, some of them are still in the memory of nation through myths and legends and became the source for spiritual national artifacts. Minaret and syrlitam in the shore of Syr Darya for Biken, Monuments for Aisha bibi and Baba azhe in Taraz, monuments of Belen ana Bolgan ana in the shores of Sarisu, monuments of Domalak ana and Karligash ene in Shymkent all these picturesque and beatiful monuments prove that statement.

According to legends with toponymy related to women it can be easily noticed Kazakh traditional gender position, which highly evaluated place of women in society according to their wisdom, character.

It is difficult to describe the contribution of women to the formation of the Kazakh people as a nation. That is why our people liken the sacred land, the sacred Motherland, the language to a noble, honorable, kind and sunny Mother. The Kazakh woman saw all the hardships with her people, rode with men in battle, took up arms, and in peacetime "shook the cradle with one hand and shook the world with the other", taught her sons and daughters the wisdom of the steppe. There is a lot of evidence for it. From ancient epics Domalak ana, Aisha bibi, Kassym khan's mother Zhagan bike, Esim khan's mother Zhaksy bike, Bopay and Aiganym, Ulpan apa only a part of women.

The image of women in Kazakh folklore is also pleasing, uplifting and touching. Their indomitable character, their unique personality, the power of art, inevitably captivate the human soul. Brave and courageous girl Nazym, unchanging faithful spouse, caregiver, friend Kurtka, tender young girl Kyz Zhibek, Bayan Sulu, sisters Aiman-Sholpan, smart and resourceful Karashash, incomparable immortal images created by unique masters. And in the written culture, the love of a beautiful woman, a kind mother in the 
works of Abai and Ibrai, S. S. Toraighyrov's Kamar, Apakai, M. Dulatov's Zhamaly, S. Kubeyev's Gaisha, S. Seifullin, B. Mailin, S. Mukanov's “free woman”, "fighting woman" and Zh. Aimautov's Akbilek, Shcherbanuy, The images of G.Musrepov "mother", "strong mother", "heroine mother", Ulpan, Aklima - new images that embody the noble qualities of our people in all their essence through wisdom, emotion and courage. In general, we understand from the teachings of the greats that the mother is the driving force of society, the basis of unity, the mirror of life that determines the image of the country, the handle of the country. The image of a mother is measured by the image and customs of that country.

\section{Methods}

In recent years, a great deal of work has been done by Kazakh researchers to study the history, language and religion, mentality, traditional culture and worldview of the Kazakh people. The desire of a newly independent country to recognize itself is a legitimate, historical necessity. The analysis of the traditional worldview of the Kazakh people on the issue of women allows us to answer many historical questions. Methodological basis is the analysis of women's issues in the Kazakh traditional worldview by historical and philosophical methods. The methods of historical and logical, comparative analysis, systematization, generalization were also used, and the authors also used the methods of generalization, synthesis, description.

\section{Results}

All works of art are rooted in folklore and find a traditional continuation. A wide range of themes, a variety of themes, immortal ideas, living ideals, which have risen to the highest level today and are included in the golden fund of world literature, have traditionally continued in the oral literature, including poetry attracted.

"Kazakh folklore, deeply rooted in antiquity and ethnic history, is represented by heroic tales, lyrical and epic poems, tales, and legends, created mainly on the basis of historical events witnessed by people. Their primary sources could be short stories about the heroism of people, distinguished by military prowess, stories about the tragic love of unhappy young people who challenged injustice, active and proactive people's imagination that revealed itself in the struggle against natural forces. They are deeply patriotic by content, poetic in presentation, imbued with a call for unity, fortitude, perseverance, and tenacity in pursuit of the goal. These stories like a drop of water reflect the fate of these people, their wisdom, and attitude toward the world. Kazakh folklore is unique; it includes more than forty genre varieties, many of which are typical only for Kazakh folklore. This folklore is inexhaustible: it includes not only heroic legends, lyrical and epic poems, stories, legends, folk songs, love and ritual songs, philosophical reflections, dedications, and instructive tales, but also many witty sayings, riddles, aphorisms, proverbs, farewell and funeral chants, lullabies, incantations, and spells, giving a complete picture of the Kazakhs' existence and world outlook" [1, p. 203].

Folklore has always been rich in aesthetics, where there is no world beyond beauty. As a product of national consciousness, they are always deeply intertwined with aesthetic thought. In the works of folklore, artistic criticism and notion are formed as a twin concept, and from the very beginning is associated with the requirement to sing beauty. Phenomena of life: a hero defended by the country, a boy and a girl who fought for their freedom, a wise old man sings in accordance with the laws of beauty.

To judge the significance of a woman 
in a nomadic society, we will have less historical sources than legends, which are the most authentic source, because legends are people's interpretation of an extraordinary event. It is known that steppe women differed from women of other Eastern peoples in that they possessed much greater independence and freedom, often taking a direct part in the fateful decisions of the people. The steppe gave birth to such types of women as a friendcompanion, a counselor of the khan, a kinswoman, a woman-wit, and, finally, a warrior woman.

The greatest respect for a woman is filled with the creators of the Kazakh epic. There, a woman is valued along with a horse and a weapon. And the most interesting is that she is personified as the batyr's (Kazakh hero's) mind, his intellectual resourcefulness, while the batyr himself is portrayed as a kind simpleminded ruffian who should always be guided and supported. But, one way or another, a woman in the steppe is always with a man.

In love epics and lyric-epic songs, the issues of human freedom and women's equality are often raised. These songs have great moral, humanistic and aesthetic significance in the education of future generations.

The Kazakh people have a tradition of respecting women. The girl was given as a guest for a few days, and she was brought up as a shard of gold, a piece of silk. If we look at the past history of the Kazakh people, who had a special respect for women, the source of tenderness and beauty, there are many women who danced, joined the group and spoke through the legendary efforts of the people. Kyzai, Karashash, Muryn, Batey, Uldai, Enen and others. The names of the tribes named after women are still known today.

Images of Juliet and Isolde in Western literature, Tatiana and Anna Karenina in Russian literature, Layli, Zukhra, Shyryn in
Eastern literature, Karashash, an ordinary woman in Kazakh literature, who won the khan with wisdom, Akzhunis, Nazym, Kurt, who honored her loyal love and accompanied her hero, Gulbarshin, Bayan, Kyz Zhibek, Aiman-Sholpan, May and Enlik, Gaisha and Shuga, who aspired to freedom and equality, were the victims of an unjust society, but they were the bright images of the people's thoughts and dreams.

Any image is based on national character. National character is formed on the basis of the peculiar psychological structure of the population. Sociohistorical, as well as geographical environment reflects the originality and peculiarities of art and literature, first of all in the national psychological structure, and then through the psychological structure. We would like, as an evidencebased argument, to quote Kazakh writer Ilyas Esenberlin, who in the last century said such important words, "The nature of the people is determined by the womanmother. Women of each people actually determine the national character. Perhaps, in the entire East, you will never find a more freedom-loving and free woman than the Kazakh woman. She never hid her face behind the tight net of the veil, she knew how to love and fight for her love, she was not afraid to hold advice together with the eldest, and, if necessary, she took a quiver with arrows, short and curve, and sat in the saddle. Kazakh legends preserved many names of brave and wise women", - said the author of the trilogy "The Nomads" [2].

In order to penetrate deeply into the manifestation of national character, it is necessary to determine the reasons for the formation and growth of the nation in every aspect of that national character. For example, the perseverance, naivety, brotherhood, hospitality, gentleness, forgiveness in the character of Kazakh women are the hallmarks of our nomadic ancestors, who have used the steppe as much as necessary. However, this is not 
a permanent metaphysical phenomenon that never changes.

When we talk about the image of women as a symbol of beauty, elegance, beauty, we must not forget that each nation has its own peculiarities in the perception and perception of beauty. For example, in the Kazakh oral literature and poetic works there are many works dedicated to the sculpture of women's beauty and appearance. The Kazakh people have many names for the eyes: for example, sheep's eye, black eye, transparent eye, smiling eye, etc. We see the natural and traditional complexion of the Kazakh beauty through the phrases "money on the forehead", "cold moon", "a braid on the wrist, a gentle squeak". The Kazakh people have always admired their daughters, called them "aq mangdaily" ("who has white forehead"), "quralai kozdi" (“who has eyes of saiga calf”, i.e. "who has beautiful round brown eyes"). Women of the Great Steppe always had a special status in the social hierarchy of the Kazakh state, that is why the Kazakh people traditionally retained a respectful and careful attitude to women - keepers of the hearth.

In folklore, the tradition of creating the image of "perfect beauty", "wonderful woman", "faithful spouse" is clearly seen in various stories, epic songs and legends. For example, in the fairy tales "Aibarsha under the moon", "Daily under the sun", "Aidai sulu Aisulu”, "Zhusup-Zylika”, "Muhabbat-name”, "Kozy Korpesh-Bayan sulu”, “Kyz Zhibek”, “Er Targyn”. In the songs "Alpamys Batyr" the devotion to the beloved, the beauty of the beauties who have been waiting for their spouses for many years, without extinguishing the fire of hope, are especially beautiful.

The nature of women and her difference from men is noticed by her beauty. The beauty is only women's feature. So, it is a logical that each woman strives for beauty, and poets, as whole people, desire for beauty.
The description of Abai concept of Beauty are reflected through following combinations: spacious forehead, bronze hair, light throat, reddish face, black eyes, eyebrow arch, the gluttony looking at her, honey lips, red flower, clean white teeth, scent smells like a flower, thy light is sunshine, friendly human, forgiving person as a cast white silver, eye is shining as a beautiful black eyes, bright face, reddish side bars, the faceted nose straight descending through the forehead, bronze black hair like a silk, struck to eyes, as a wave and etc. From these named combinations we can clearly notice the suitable meaning about the beauty of Kazakh Nation. One line of them is the combinations which have formed earlier on Kazakh people's consciousness, and another of them is pattern of words which poet constructed.

Educated, arrogant, cool-minded, intelligent, strong-willed women with great spirit in our original literature Akkozy, Gaukhar (I. Esenberlin “Nomads”), Aisheshek-begim (M. Magauin “Alasapyran"), Bopay (A. Kekilbayev “Urker”, “Elen-alan”) etc. can be called. They are delicate, sharp-eyed, noble and courageous. Such images are Kulshan (H. Esenzhanov “White Ural”), Botagoz (S. Mukanov “Botagoz"), Aigansha, Bobek, Kenzhekey (A. Nurpeisov "Blood and sweat"), Rukhiya, Arshagul (S. Smataev "Elimay").

M. Auezov, S. Mukanov, Zh. Aimautov, M. Magauin, I. Esenberlin, A. Kekilbaev and others were able to show the morality and behavior of a woman by depicting the delicate phenomena of a woman's face.

\section{Discussion}

In the traditional Kazakh worldview, there are original categories that express personality and individuality. Such a concept includes "nobility". Nobility is a characteristic of both men and women, rich and poor. Not everyone has 
it. Zh.Moldabekov divides the levels of nobility as follows: nobility of race and blood, nobility of the citizen, nobility of the people [3, p. 208].

In particular, the concept of "Kazakh woman" in the works of poets to the values of the above national worldview.

Indeed, in folk legends and songs, historical stories, genealogies, national customs and traditions, it is often said that our ancestors paid special attention to their ancestry. According to L. Gumilev: “... Special attention is paid to the origin of his mother. For example, the reason for the removal of Prince Toremen from the throne was "the low origin of his mother. Of course, this is just a ruse, a maneuver of his political enemies, but look at the interestingness of that argument" [4, p. 72].

"Revealing the essence of the concept of happiness, which occupies an important place in the epic heritage of the Kazakh Zhyrau, Kazakh thinkers associate happiness with married life, it is a part of happiness ... characteristic of all thinkers of the period" [5, p. 93].

"Women were important social and economic partners with their husbands in Kazakh society" [6, p. 33]. The importance of the issue of a good wife in Kazakh life can be seen in the fact that there were no poets who did not address this issue. How to recognize a good wife and a bad husband? In turn, the main quality of a good woman is to know the dignity of a man, while the bad quality of a bad woman, on the contrary, is a lack of respect for her husband, which is clearly reflected in the poetry of poets.

Legends of distant times brought to us the sung by narrator-akyns (improvisatory poets and singers) heroic and majestic image of the steppe woman - daughter, mother, wife, ruler, and batyr (heroine). The Kazakh people have always admired their daughters, their beauty, their intelligence and valiant appearance. And women of the Great Steppe always used a special status in the social and political hierarchy of the Kazakh state. According to the true laws of the Kazakh people, the girl was not meant for entertainment as a bond slave, she was equal in a severe nomadic life, and therefore, could only become a wife, mother, and, when required, a defender of the motherland. From an ancient period in the Kazakh language, for example, such archaisms were preserved: "ot-anasy" the main keeper of the hearth; "ot-agasy" - the head of the family.

In the history of the Kazakh people there were many poets, heroes and daughters who spoke in front of a square group, ruled the country, led the country in difficult times, attacked the enemy with a spear in their hands.

Summing up all this, we see a progressive view of the place of men and women in the world in the works of poets, who formed the Kazakh philosophy in the form of wisdom and understanding.

In the works of poets there are images of a man, a mother of the country, a good wife, a bad wife.

In general, the level of culture of any nation is reflected in the care for women in society, which can be seen in the attitude of Kazakhs to women as wives, mothers and daughters. In the Kazakh society, the attitude of respect for women as a mother, pity as a girl, respect as a sleeve, love as a spouse prevails. "The first principle "Ana Kurmetteu, Ana Sutin Aktau" or "Respecting the mother, the intention to justify the milk of the mother" is the greatest and very first principle that is accepted by those holding Kazakh philosophies. From one hand a man ought to preserve the moral and ethical qualities that were laid down by the mother and transferred as an ethical code. Every person should to live according to the mother's moral expectations. He must justify the milk of the mother, the gene that she passes to her baby. On the other hand, according to the ideas in the 
Turkic nomadic culture, Umai-ene, the angel-spirit is the patron of mothers and pregnant women, which also had been associated with the native Earth-Water and protects everyone to be born. Therefore, each person should strive to justify the milk of Mother-Earth" [7, p.70].

In general, the characteristic of the peoples of the East, including the Kazakh people - respect for the elder, never to oppose him, this is a pure natural character of a Kazakh woman who thinks of loyalty to her husband.

In the Kazakh worldview, the main functions of a woman - creativity, procreation, guardian of the tribe, etc. The book of the Russian ethnographer I. V. Stasevich "The social status of women from Kazakhs: traditions and modernity" is devoted to the study of the position of the Kazakh woman in traditional and modern culture. The attention of the author is focused on changes in the social status of the Kazakh woman that have occurred over the past 200 years and are associated with the cardinal transformation of the traditional nomadic society. His conclusions about the specifics of the social status of women author confirm the arguments about the role of women in the rituals of the life cycle. I. V. Stasevich believes that "traditionally Kazakh women are the guardians of the family traditions and values of Kazakh ethnos... Respect for a woman is present in each Kazakh national tradition or ceremony" [8, p. 2409].

The history of Kazakh people clearly demonstrates that the Kazakh woman in her social status and status in the social hierarchy differed from the women of other Eastern peoples. The great steppe people gave the woman a special tribute of respect as to the keeper of the home and mother. A Kazakh woman could be a worthy companion, a counselor, a support for her father, husband, brother. She had the opportunity to get an education, learn to play musical instruments, sing, participate in aitys (singing poetic competition) (Beyond the silk road, n.d.).

The daughters of the Kazakh steppes were not just an ornament, but also the pride of their fellow tribesmen. Kazakh women have always made a great contribution to the culture and spirituality of their people, occupying an equal position in society. Daughters of the Kazakh people differed from their peers - representatives of Eastern and other peoples, by having greater independence, freedom and a developed sense of dignity. Owing to natural qualities, ingenuity, open and strong-willed character, the steppe woman participated in making crucial decisions for the people. In all Kazakh legends and stories, the sublime and majestic image of a Kazakh woman, daughter, mother, wife, ruler, is sung.

Attitude to the woman was emphatically respectful, chivalrous. The son, entering the yurt, bowed first to his mother, and then to his father. The Orkhon inscriptions with the greatest pathos describe the battle in which Kul Tigin defended the horde, where there were his kinswomen who were threatened with death.

The attitude of parents and relatives to an unmarried girl is often more caring than to boys. She seems to be in the status of a "guest" in her family, and therefore, should be endowed with great attention and love than the boys who remain in the family of their father and will inherit his property.

Every Kazakh woman took an active part in the fate of her family. Conditions for the existence of the family depended on the actions and work of women. Therefore, women in the home and family issues acted freely and at ease, engaged in affairs at their discretion and were real helpers of their husbands.

The national consciousness of the people, the calm, faithful spirit of the Oriental woman, their politeness, the struggle for the welfare of the family, the willingness to sacrifice themselves for the 
sake of their beloved spouse and children have a common place in the literary works of each period, each nation.

\section{Conclusion}

Social, economic, political and cultural changes and modernization in modern society have their own impact on the formation of the image of the Kazakh woman. The image of the Kazakh woman in the past had a variety of characteristics. In accordance with the historical and cultural development of each epoch, its images were given mythological, religious, philosophical and literary interpretations. As a result, the image of a woman was symbolically reflected in the spaces of legends, epics, folklore, fiction and art. Neither the singers nor the compilers of the Kazakh national genealogy left the woman in the genealogy and genealogical data. In the formation of the Kazakh nation, in the presence of a unique language, customs and traditions that survived the tragedy of the great steppe, the role of the Kazakh girl, who became a mother, a special place, was special. "Women are often depicted in the heroes' songs as the hero's beloved companion, reliable companion, wise friend. The introduction of a fair and just view of women in the oral literature shows that intelligent, knowledgeable and wise people come from women as well. Such women are included in the song along with men, creating a positive image of them" [9, p. 22].

In the works of poets the images of the mother of the country, the beautiful, the masculine, the good wife, the bad wife are created and sung. In the Kazakh worldview, the main quality of a good woman is to know the value of words, the value of the country, a good woman should also know the value of a man, and the characteristic of a bad woman, on the contrary, is disrespect for her husband.

At the beginning of the twentieth century in Kazakhstan there was a time when cultural and educational ideas began to spread and the intelligentsia began to form. Continuing the process set by Abai, Kazakh intellectuals created a new image of women. Abai was concerned about the future of the nation and the image of the epoch and paid special attention to the education of girls and women. The great poet portrayed not only a noble and intelligent woman, but also an unpleasant woman. In the works of Kazakh intellectuals of the early twentieth century, women's inequality has become a topical issue. Kazakh educators of this period realized that the fate of the nation could not be decided without the right decision of the Kazakh woman.

"The image of a modern Kazakh woman shows signs of tradition and postmodernism" [10]. "One of contemporary tendencies amongst Kazakh women in modern society is aspiration to be postmodern. It is not directed to life with postmodern conditions, but to become postmodern as an individual" [11, p.13].

Today, all national cultures are fully aware of the process of globalization and the influence of mass culture, which is its "child". There is no doubt that traditional values and symbolic images, inherited from ancient times, are undergoing radical changes, including the change in the image of women in the modern Kazakh mentality. At the same time, along with the transformation of centuries-old images in the traditional consciousness, the role and social activities of the Kazakh woman in modern culture led to the formation of new images.

Preservation of the positive traditional aspects of the image of women is one of the most important issues for the nation. Advertising and cinema, which are the carriers of popular cultural values, play an important role in creating the image of the Kazakh woman today. This is because under the influence of the media, especially on television, women try 
to create their own image, imitating the images in the movies. The influence of globalization on the image of the Kazakh woman in modern culture can not be ruled out, but if we study the relationship between tradition and innovation in the image of our contemporaries, it is clear that traditional national character prevails.

\section{References:}

1. Mayemirov A., Khalykov K., Nurpeis B. "Ethnic and cultural aspects in the development of Kazakh theatres during the independence period: the problems of human existence" // Folklore-electronic journal of folklore, 2015, 201-225 p.

2. Esenberlin, I. "Sokrovennoe: Mysli. Izrecheniya. Vospominaniya" [Innermost: Thoughts. Notabilia. Memories], Almaty. Retrieved from http:// pushkinlibrary.kz/exhibitions/esenberlin/ya_napisal.html, 2001

3. Moldabekov Zh. The abode of nobility is the support of personality. Almaty: Sanat, 1998, 208 p. (in Kazakh)

4. Gumilev L. Ancient Turks. - Almaty: Bilim, 1994. 478 p. (in Kazakh)

5. Thinkers of the Kazakh steppe in the XVIII-XIX centuries. / Nurmuratov S., Akhmetov M., Alzhan K., Barlybaeva G., Almaty: Institute of Philosophy and Political Science, 2004, 310 p. (in Kazakh)

6. Sabol, S. "The Sioux and the Kazakhs", In the Touch of Civilization: Comparing American and Russian Internal Colonization, 2017, (pp. 33-68), Boulder, Colorado: University Press of Colorado.

7. Nurysheva G., Amrebayeva Z., Amrebayev A. The Kazakh Ethical Tradition and Anti-nuclear Ethics. In: Bombaerts G., Jenkins K., Sanusi Y., Guoyu W. (eds) Energy Justice Across Borders. Springer, Cham. 2019, p. 69-87.

8. Abdikadyrova Zh., Kadyrov Zh., Talaspayeva Zh., Sharypkazy N. The role of women in kazakh nomadic society // The Turkish Online Journal of Design, Art and Communication - TOJDAC, September 2018 Special Edition, p. 2404-2419.

9. Musine Galima. Turan'in Alp Kizlari. Sato Turkiyat matb. - Istanbul, 2001 (in Turkish).

10. Gabitov T., Adaeva G., Shamahay S. Woman Image of in Modern Kazakh culture // International Conference on Identity, Culture and Communication, Paris, France, 27-28 June, 2013.

11. Alimzhanova A. Feminism and symbolic-mental description of Kazakh women. Central Asian Journal of Art Studies. Vol. 4. №1, 2019. p. 7-18. 


\section{Гульжихан Нұрышева, Бану Калдаева}

Әл-Фараби атындағы Қазақ ұлттық университеті

(Алматы, Қазақстан)

\section{ДӘСТҮРЛІ ҚАЗАҚ АҮНИЕТАНЫМЫНДАҒЫ ӘЙЕЛ БЕЙНЕСІ}

\section{Аңдатпа}

Мақала қазақ халқының дәстүрлі дүниетанымындағы әйел бейнесіне арналған. Дәстүрлі дүниетаным тарихи типтерге жіктеліп, осы сатыларда орын алған әйел мәселесіне байланысты түсініктер мен үрдістер эволюциясы зерттеледі. Әйел мәселесін дәстүрлі дүниетаным шеңберінде қарастырудың мәні зор. Өйткені жыныстардың қоғамдық рөлі туралы үрдістер мен стереотиптер ұрпақтан ұрпаққа дәстүр бойынша жалғасып келе жатқан, тамыры тереңге кеткен түсініктер негізінде қалыптасады. Бұл түсініктер қоғам дамуының ұзақ тарихы жүзінде дамып отырады және оның әртүрлі: тарихи, әлеуметтік, экономикалық, саяси, мәдени, діни қырлары болады. Бұның бәрінің орталық ядросы халықтың дүниетанымы болғандықтан, дәстүрлі дүниетанымдағы әйел бейнесін талдау аса маңызды. Бұл қоғамның әйел мәселесіне байланысты түсініктерінің эволюциялық жолын және оның негізін түсінуге мүмкіндік береді. Қазіргі жаһандану жағдайында өзіндігіңді, өзгешелегіңді сақтау үшін де, көптеген мәселелерге, соның ішінде әйел мәселесіне байланысты қазақ халқының дәстүрлі құндылықтар жүйесін, еркек пен әйелдің қоғамдағы орны мен рөлі туралы түсініктер жүйесінің эволюциясын, гендерлік қатынастарға қатысты халықтың тарихи тәжірибесін зерттеу қажет. Қазіргі әлемде мәдени жаһандану мен ұлттық жаңғыру қатар жүреді. XXI ғасыр мәдениетінде, бір жағынан, бүкіл планетаның жалпы әлемдік мәдениеті қалыптасуда, екінші жағынан, әр ұлтың мәдени әртүрлілігіне және оның дамуына қызығушылық артып келеді. Бүгінгі қазақ әйелінің бейнесіндегі дәстүрлер мен қазіргі заманның өзара байланысы мәдени мұра мен қазіргі мәдениеттің арақатынасында айқын көрінеді. Қысқа уақыт ішінде ешқандай ол күшпен жасалмайды; халықтың мәдениетін реттейтін факторлар ғасырлар бойы қалыптасады. Сондықтан қазақ мифологиясындағы ана бейнесін, қазақ шежіресіндегі ана бейнесін, батырлар туралы эпостардағы әйел образдарын, сондай-ақ ақын-импровизаторлар шығармашылығындағы әйелдер бейнелерін талдаудан бастап, қазіргі заманғы мәдениеттегі қазақ әйелінің бейнесін жүйелеу маңызды.

тірек сөздер: әйел бейнесі, дәстүрлі қазақ дүниетанымы, әйел болмысы, «қазақ әйелі концептісі", халық ауыз әдебиеті. 


\section{Гульжихан Нурышева, Бану Калдаева}

Әл-Фараби атындағы Қазақ ұлттық университеті

(Алматы, Қазақстан)

\section{ОБРАЗ ЖЕНЩИНЫ В ТРАДИЦИОННОМ КАЗАХСКОМ МИРОВОЗЗРЕНИИ}

\section{Аннотация}

Статья посвящена образу женщины в традиционном мировоззрении казахского народа. Традиционные мировоззрения делятся на исторические типы, изучается эволюция представлений и тенденций, связанных с проблемой женщин, которая имела место на этих этапах. Важно рассматривать проблему женщин в контексте традиционного мировоззрения. Это связано с тем, что тенденции и стереотипы о социальной роли пола формируются на основе глубоко укоренившихся представлений, которые традиционно передаются из поколения в поколение. Эти концепции развиваются на протяжении долгой истории общества и имеют разные аспекты: исторический, социальный, экономический, политический, культурный, религиозный. Поскольку центральным стержнем всего этого является мировоззрение людей, важно проанализировать образ женщины в традиционном мировоззрении. Это позволяет нам понять эволюционный путь понимания обществом проблем женщин и его основы. Чтобы сохранить свою идентичность в условиях сегодняшней глобализации, необходимо изучить традиционную систему ценностей казахского народа, эволюцию системы представлений о месте и роли мужчин и женщин в обществе, исторический опыт народа применительно к гендерным отношениям. В современном мире глобализация культуры и национальный ренессанс идут рука об руку. В культуре XXI века, с одной стороны, формируется общая мировая культура всей планеты, с другой стороны, растет интерес к культурному разнообразию каждой нации и ее развитию. Взаимосвязь традиций и современности в образе сегодняшней казахской женщины ярко отражается во взаимосвязи культурного наследия и современной культуры. Ни одна культура не создается силой за короткое время, факторы, регулирующие культуру народа, формируются веками. Поэтому важно систематизировать образ казахской женщины в современной культуре, начиная с анализа образа матери в казахской мифологии, материнства в казахской генеалогии, образов женщин в эпосах про батыров, а также образов женщин в произведениях поэтов-импровизаторов.

Ключевые слова: образ женщины, традиционное казахское мировоззрение, сущность женщины, «концепция казахской женщины", фольклор. 


\section{Авторлар туралы мәлімет:}

Нұрышева Гүлжихан Жұмабаевна - философия ғылымдарының докторы, Әл-Фараби атындағы ҚазҰУ философия кафедрасының профессоры (Алматы, Қазақстан) ORCID ID: 0000-0001-6640-8111

email: gulzhikhan-nurysheva@yandex.kz

Калдаева Бану Станбековна - Әл-Фараби атындағы ҚазҰУ философия кафедрасының 3 курс докторанты

(Алматы, Қазақстан)

ORCID ID: 0000-0003-0409-8423

email: banu_k@bk.ru

\section{Сведения об авторах:}

Нурышева Гулжихан Жумабаевна - доктор философских наук, профессор кафедры философии Казахского национального университета имени Аль-Фараби

(Алматы, Қазахстан)

ORCID ID: 0000-0001-6640-8111

email: gulzhikhan-nurysheva@yandex.kz

Калдаева Бану Станбековна - докторант 3 курса кафедры философии Қазахского национального университета имени Аль-Фараби

(Алматы, Қазахстан)

ORCID ID: 0000-0003-0409-8423

email:banu_k@bk.ru

\section{Authors' bio:}

Nurysheva Gulzhikhan Zhumabaevna - Doctor of Philosophy, Professor of the Department of Philosophy, Al-Farabi Kazakh National University (Almaty, Kazakhstan) ORCID ID: 0000-0001-6640-8111

email: gulzhikhan-nurysheva@yandex.kz

Kaldayeva Banu Stanbekovna - PhD candidate in the Department of Philosophy, Al-Farabi Kazakh National University

(Almaty, Kazakhstan)

ORCID ID: 0000-0003-0409-8423

email: banu_k@bk.ru 